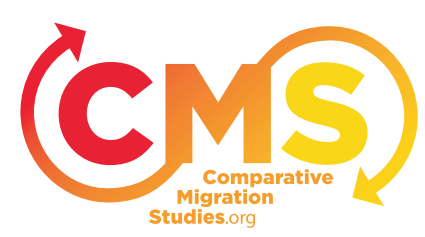

\title{
The Transfer of Pre-departure Integration Requirements for Family Migrants Among Member States of the European Union
}

\author{
Saskia Bonjour
}

CMS 2 (2): 203-226

DOI: $10.5117 / C M S 2014.2 . B O N J$

\begin{abstract}
Over the last decade, six EU member states have introduced pre-departure integration requirements for family migrants. The Netherlands was the first to introduce such 'civic integration abroad' policies. Its example has been followed by Austria, Denmark, France, Germany, and the UK. While it is well established in the literature that the European Union has played a crucial role in the proliferation of these and similar mandatory integration policies, the question why and how these policies have spread through Europe has not been subjected to analytical scrutiny. This paper shows that while the EU has functioned as a platform for the exchange of ideas, EU institutions such as the Commission have strived to obstruct this process. The only actors promoting the transfer of pre-departure integration measures were national governments. For these governments, representing such measures as a 'common practice' among member states was a strategy to build legitimacy for restrictive reform.
\end{abstract}

Keywords: pre-departure integration requirements; civic integration policy; policy transfer; Europeanization; family migration policy

\section{Introduction}

In March 2005, the Dutch Parliament adopted a policy that was radically innovative: henceforth, foreigners who wanted to come to the Netherlands to live with a family member would have to demonstrate a basic level of knowledge of Dutch language and society, before being admitted to the country. In the next six years, five European countries followed the Dutch example: Austria, Denmark, France, Germany, and the UK now require 
family migrants to take the first steps in learning about their new country's language and - in France and Denmark - customs abroad, before leaving their country of origin. ${ }^{1}$ This paper examines the role of the European Union in this proliferation of pre-departure integration requirements for family migrants among EU member states.

Since the late 199os, more and more European countries have introduced civic integration programs, which enable or require migrants to acquire language skills and country knowledge. Pre-departure integration conditions represent the newest and most radical extension of this trend. The proliferation of civic integration policies in general and pre-departure integration requirements in particular has received increasing attention in the literature (cf. Carrera 2006; Goodman 2010, 2011; Groenendijk 2011; Jacobs and Rea 2007; Joppke 2007; Van Oers et al 2010 - see also the PROSINT and INTEC projects ${ }^{2}$ ).

It is well-established in this literature that the European Union has played a crucial role in the proliferation of these policies in many member states, including countries which are not bound by EU migration law such as Denmark and the United Kingdom. Authors point to non-binding policy instruments like the Common Basic Principles on Migrant Integration, the European Integration Fund, Handbooks on Integration and the European Website on Integration, through which member states have been encouraged to stimulate migrants to learn about their host society's language, institutions, and culture. They also point to binding EU law on immigration, notably the Long-Term Residents Directive and the Family Reunification Directive, in which the notion of submitting entry and residence to integration requirements has been inscribed (Joppke 2007; Carrera and Wiesbrock 2009; Carrera 2006; Guild et al 2009; Böcker and Strik 2011). Groenendijk (2004) emphasises that this approach to integration as a condition for residence rights was introduced to the European agenda by a select group of member states, most notably the Netherlands, Germany, and Austria. As a result of their successful efforts, 'the common EU policy is now a vehicle for legitimising and promoting (...) policies and programmes, which use integration in a civic and conditional fashion' (Carrera and Wiesbrock 20o9: 36 ).

However, the question of how and why these policies have proliferated so fast in Europe has not been satisfactorily answered, mostly because the process of transfer itself has not been subject of analysis until now. As a result, much less is known about to which extent and how national policymaking processes in the field of civic integration have been influenced by EU and other member states' policies. This is especially true for the transfer of pre-departure integration conditions. 
Goodman (2011), in an article in which she argues convincingly that pre-departure integration measures aim at migration restriction, rather than at migrant integration, does touch upon the issue of transfer indirectly. She states that the Family Reunification Directive has set 'a supranational precedent that created the political opportunity for national implementation' and 'created a legitimacy that makes it possible for member states to link integration requirements to immigration' (Goodman 2011: 235, 242). Besides this supranational source, Goodman points to learning among member states, with Dutch pre-departure integration policies serving as a 'model' that has 'inspired' other member states (Goodman 2011: 250-252). In this article, I will argue that Goodman is right in describing 'horizontal' mimicking processes among member states as crucial to the proliferation of pre-departure integration measures, but that she over-estimates the 'vertical' role of supranational sources such as the Family Reunification Directive.

I will show that the European Union has played a much more ambiguous role. As a result of the introduction of European migration policies, the EU has indeed come to function as a platform for exchange and promotion of policy ideas among member states, including the idea of pre-departure integration measures. However, supranational law and supranational institutions only played a minor part in facilitating this transfer. Different categories of actors operating at EU level have influenced the process of transfer in opposite ways (cf. Block \& Bonjour 2013). The legitimacy of the Family Reunification Directive as a legal basis for pre-departure integration measures was controversial and weak from the very start. EU institutions, most notably the Commission, have strived to obstruct rather than promote the diffusion of pre-departure integration policies. Instead, member states were the main actors of transfer.

The following section sets the scene by providing a brief comparative description of pre-departure integration requirements in Austria, Denmark, France, Germany, the Netherlands, and the UK. In the third section, I explore the role of the EU in the transfer of these requirements, arguing that the EU served as a platform for horizontal diffusion among member states. The fourth and final section presents an analysis of government documents and parliamentary deliberations in five out of six countries concerned, omitting the Danish case because my language skills do not permit access to Danish primary sources. ${ }^{3}$ This analysis shows that policy transfer was aimed not at rationally identifying the most effective policy solution, but at legitimation: national politicians build legitimacy not primarily by comply- 
ing with formal EU norms, but by following each other's lead, i.e. by fitting into the informal norm set by shared policy practice.

\section{Six versions of pre-departure integration requirements for family migrants ${ }^{4}$}

Pre-departure integration requirements for the admission of family migrants are a recent invention. Previously, language requirements have been used in migrant selection procedures where language skills were directly relevant to the grounds for admission, i.e. in the selection of labour migrants or of ethnic migrants (Groenendijk, 2011). For example, as of 1997 Germany required so-called Aussiedler to prove their belonging to the German nation by demonstrating German language skills (Block 2012). The innovation of the new pre-departure integration requirements lies in that now, language requirements are applied to migrants whose claim to admission is grounded in the moral value of family life - a claim on which their language skills have no bearing. The first time the admission of family migrants was submitted to integration conditions was in the 1990s in Germany, where foreign children between 16 and 18 years old were required to prove either proficiency in German or ability to integrate before being allowed to join their parents (Seveker and Walter 2010). Also in Germany, in 2005, family members of Aussiedler were required to demonstrate a basic level of German language skills before being granted access to German territory and citizenship (Block 2012). The idea of applying language requirements generally to the first admission of non-EU family migrants was first launched in the Netherlands in April 2000 by Jaap de Hoop Scheffer, then leader of the Christian Democrat Members of Parliament (Dutch Lower House 2000).

Thus, one might debate whether pre-departure integration measures for family migrants are a German or a Dutch invention. Whatever the case may be, the Dutch were the first to lay down in law that non-EU family migrants would be required to fulfil pre-departure integration requirements. The Dutch Law on Civic Integration Abroad entered into force in March 2006. The Danish were next to adopt pre-departure measures in April 2007, but their policy entered into force only in November 2010. Germany and France followed closely, with pre-departure integration conditions entering into force in August 2007 and January 2008 respectively. The British government first announced its intention to introduce a language requirement for foreign spouses in March 2007, but the Labour government put off the actual implementation. It was the current Conservative-Liberal coalition 
which introduced the requirement in November 2010, only six months after entering office. Austria is the most recent country to have followed suit, with language requirements adopted by Parliament in April 2011 and entered into force in July 2011.

These six versions of pre-departure integration measures bear striking resemblances. In all six countries, the new integration condition applies to third-country nationals ${ }^{5}$ who wish to immigrate to join a family member. In the UK, Germany, and Denmark, the integration requirement only applies to migrants who come to join a spouse or partner, while in Austria and the Netherlands it also applies to adult children, and in France also to children aged 16 or older. Family members of refugees are exempted in all six countries, as are family migrants who have completed a certain level of education in the host country's language. Germany and the Netherlands exempt certain (Western) nationalities. As a result of court judgements discussed below, Austria and the Netherlands also exempt Turkish nationals. Austria, the Netherlands and the UK exempt spouses of high-skilled migrants. Germany and the UK exempt family migrants with specific academic or professional qualifications.

In all six countries, family migrants' knowledge of language is tested at a very basic level. In Austria, Germany, the Netherlands, and the UK, language skills are tested at the lowest level of the Common European Framework of Reference for Languages (ECRF), which is level A1. The Netherlands originally tested at a level created especially for the purpose of pre-departure testing, namely level A1 minus. Inspired by the Germans testing at A1, the Dutch have raised the level of their exams to A1 as of January 2011. Denmark and France still follow the original Dutch example, evaluating at level A1 minus. In addition to the language test, the Netherlands and Denmark also test knowledge about the host society, while France includes knowledge of 'the values of the Republic' in its evaluation.

With the exception of France, none of these countries provide courses to prepare for the test. Family migrants are to find and finance these courses themselves. The UK and Germany provide a list of accredited course providers to help applicants select a quality course, while Denmark and the Netherlands have compiled a 'practice pack' which applicants can purchase. In contrast, France offers courses about its language and values for free. This is the first major difference between the six existing versions of pre-departure integration.

The second, most important difference is that while Austria, Denmark, Germany, the Netherlands, and the UK require that applicants pass the test before they are granted a residence permit, France requires only that 
family migrants participate in an evaluation and, if the results of this evaluation are insufficient, in a course. If the applicant participates duly in the evaluation and course but is not able to reach the required level, he or she is still admitted to France. Thus in France, unlike in the five other countries, there is an obligation of effort, not of result. All in all, the French measure poses significantly less of an obstacle to family migration than the pre-departure integration requirements in the five others countries: family migrants do not have to pass a test, but only to participate in a course which is offered for free. This different approach to pre-departure integration is due to the specific domestic context in France, where left-wing opposition to these policies was much stronger than in the other five member states, and where government politicians were more wary of opposition by the courts (Bonjour 2010).

Finally, in Denmark, unlike in the other countries, the test is not taken abroad. The Danish originally intended to implement the exams in Danish consulates abroad, following the Dutch example. However, as in the French case, the domestic policy making process led to a different outcome. Examination abroad was found too costly, which is why a more cost-efficient system was developed. Family migrants are granted a special short-term visa to come to Denmark for 28 days in order to pass the integration test. Once in Denmark, they can extend this 'procedural stay' to three months, during which time they may follow a course if they wish. If the test is not passed within three months, the residence permit is refused and the applicant must leave Denmark.

It is probably no coincidence that these six countries are at the forefront of the policy turn towards integration requirements (cf. Goodman 2010). First, Austria, Denmark, France, Germany, the Netherlands, and the UK belong to the 'older' immigration countries in the European Union. All six countries except the UK had formal recruitment programs for labour migrants in the 1960s and early 1970s; the UK, France and the Netherlands have known significant post-colonial migration flows throughout the postwar period; and all six countries have experienced increasingly substantial refugee flows starting in the 1970s. Persons born outside of the EU make up between 7,5 and 9 per cent of the population in all six countries except in Denmark, where their percentage is 6,3 (Eurostat 2011a). Second, the socio-economic situation of the population of non-EU migrant origin is cause for concern in all six countries. The difference in employment rate between the general population and the non-EU born population ranges from 13 percentage points (Germany and the Netherlands) to 9 percentage 
points (UK) in these six countries, while the average employment gap in the ${ }_{7} \mathrm{EU}$ member states is 7 percentage points (Eurostat 2011b: 65).

Most importantly, there are similarities in the way in which the issue of migration and integration is framed by policy-makers. The politicisation of migration and integration has been rising in these six countries since the 1990s, to reach new peaks since the turn of the century (cf. Bonjour 2010; Ersbøll 2010; Guild et al 2009; Scholten et al 2012). In all six countries, politicians worry that socio-economic cleavages overlapping with cultural and ethnic distinctions are threatening the cohesion of their societies. According to dominant political discourse, social cohesion depends on all members of society sharing a minimum level of common values and practices. Also, emphasis is put on the responsibility of migrants for their own integration. Obligatory integration programs in general, and pre-departure integration requirements in particular, are attractive policy solutions for policy-makers who share this problem perception. These requirements make migrants responsible for acquiring skills that should enable them not only to find a job and raise their children to be successful in school, but also to integrate socially and to adhere to the values and identity of their new home country.

Pre-departure integration policies are also very much part of the recent restrictive turn in family migration policies in Europe. Since the mid2000s, many European countries have tightened income, age, and housing requirements for family migration and sharpened controls on sham marriages (Block and Bonjour 2013). Austria, Denmark, France, Germany, the Netherlands, and the UK are at the forefront of this restrictive turn. Family migration is problematized, first because it is 'subie' rather than 'choisie', i.e. endured rather than chosen, as Nicolas Sarkozy famously put it: family migrants cannot be selected based on socio-economic criteria. Second, family migration is associated with failing integration, where 'traditional', 'non-Western' norms are seen to push young people of migrant background to choose a partner from their own or their parents' country of origin, thus reproducing the pattern of failing integration from generation to generation (Bonjour and Kraler, forthcoming). Pre-departure integration measures are expected to contribute to solving the 'problem' of family migration.

It is worth noting that this convergence towards a common policy paradigm and a common policy practice cannot be explained by party politics, i.e. by the dominance of a particular party family in these six countries. The introduction of pre-departure integration measures has been initiated by left-wing as well as right-wing politicians. In the Netherlands, the centreRight Balkenende coalition proposed the Law on Civic Integration Abroad, but the Social Democrats voted in favour in 2004 - and the level of the 
language test was raised by a Social Democrat minister in 2010 (Bonjour and Vink 2013). Both in Germany and in Austria, pre-departure integration measures were introduced by a coalition of Christian Democrats and Social Democrats - at the initiative of the right-wing coalition party surely, but still with the support of the Left. In the UK, it was actually a Labour MP who first proposed subjecting foreign spouses to pre-entry language tests in 2001, and it was the Labour government under Gordon Brown which first tabled the policy proposal, even if it was the current Conservative-Liberal Cameron government which actually implemented it (Scholten et al 2012). In Denmark, the integration test at entry was introduced by the LiberalConservative government with support of the Far-Right Danish People's Party, but also of the political Left (Ersbøll 2010). The sole exception was France, where pre-departure integration measures were introduced by the UMP-government against the strong opposition of the entire left-wing opposition, including the Parti Socialiste. The fact that pre-departure integration requirements were a great deal more controversial in France than elsewhere may go a long way towards explaining why the French policy on this issue is by far the least restrictive (Bonjour 2010).

The question why the 22 other member states have not introduced predeparture integration requirements (yet) can only be answered tentatively here, since these 22 member states were not subjected to empirical scrutiny in this study. However, perhaps at least part of the explanation lies in the fact that the Southern member states, Finland, and Ireland as well as the member states in Central and Eastern Europe have only recently gone from being countries of emigration to being countries of immigration. Immigration and integration have until now been framed and managed very differently in the 'new' immigration countries of Europe. While restrictive tendencies may certainly be observed, the turn towards civic integration requirements appears to be much less pronounced than in 'older' immigration countries. This is also true for Luxemburg, where immigration is predominantly highly-skilled and of European origin. In Belgium, predeparture integration measures are favoured by a majority among Flemish politicians, but blocked by their French-speaking colleagues (Jacobs 2011). In Sweden finally, family migration policies have not taken the restrictive turn which can be observed in the other 'old' immigration countries. According to Borevi (forthcoming), this is due to the absence of far-Right pressure as well as to the dominance of the universal welfare state ideology in Sweden. 


\section{The European Union as a platform for exchange}

In September 2003, the Council of the European Union adopted EU Directive 2003/86/EC on the Right to Family Reunification. This Directive was the very first piece of Community Law about family migration. It lays down minimum norms for the conditions under which third-country nationals living in a member state must be allowed to bring their family members over. For instance, it states that member states may introduce an income requirement to ensure economic self-reliance and a minimum age of no more than 21 years. Member states are free to set less stringent conditions than those allowed by the Directive but they may not introduce more restrictive policies. The Directive is directly binding upon the member states, and the Commission and Court see to it that national policies respect the boundaries it sets. Thus, for the very first time, member states' family migration policies for third country nationals have been subjected to EU-law. One might expect the proliferation of pre-departure integration conditions among member states to be a result of this new legislation: in fact however, the Directive has merely facilitated the transfer, but not caused it directly.

Article 7.2 of the Directive states that 'Member States may require third country nationals to comply with integration measures, in accordance with national law'. Thus, integration measures for family migrants have been inscribed into the Directive. Still, this clause does not provide sufficient explanation for the way pre-departure integration requirements have travelled among member states, for three reasons. First, two out of the six member states which have introduced these requirements are not bound by the Directive. Denmark opted out of the European Asylum and Migration Policy when it negotiated the Amsterdam Treaty and the UK opted out of this Directive. Second, article 7.2 is a so-called 'may'-clause, a 'soft' clause: it allows member states to introduce integration measures, but it does not oblige them to do so. If it was a hard clause, the number of member states having introduced such measures would not be limited to six. Third and finally, article $\mathbf{7 . 2}$ of the Directive is quite vague: it does not specify, for instance, that these 'integration measures' should consist of language evaluations. Crucially, it makes no mention at all of such evaluations taking place before entry or conditioning admission to the country. Therefore the Directive cannot be considered the source of the idea of 'pre-departure' integration measures, and cannot explain the similarity of the measures which the six member states have introduced.

However, while the Directive has not directly obliged or pushed member states to introduce pre-departure integration measures, it has facilitated 
their transfer, primarily by creating opportunities for the diffusion of knowledge about pre-departure integration measures among member states. The negotiations that led to the adoption of the Directive were a crucial episode in this regard. At the time, none of the member states applied pre-departure integration requirements to family migrants. Article 7.2 about integration measures was introduced into the Family Reunification Directive at the initiative of Austria, Germany, and the Netherlands. According to Commission officials interviewed by Tineke Strik (2011), those three member states had very different intentions at first. Only the Netherlands wanted to introduce a new entry condition for family migrants. The proposal for the Dutch Law on Civic Integration Abroad had not even been presented to Parliament yet at the time, but since the idea of an integration exam before entry was 'in the air', the Dutch delegation wanted to make sure the new Directive would allow for it. The Germans wanted to oblige family migrants to participate in a course once they were in Germany, while the Austrians wanted to be able to refuse to prolong a permit if a family migrant had not successfully integrated. A member of the Dutch delegation stated that 'in the course of the negotiations, the Dutch Law on Civic Integration Abroad took a clearer shape, and that was a shock to everybody. Now that the law is being finalised, they are all very positive about it' (Strik 2011: 110). Thus, in the course of the negotiations, civil servants and ministers responsible for immigration policies were introduced to the idea of pre-departure integration measures, and the Dutch had the opportunity to explain how their policy of 'civic integration abroad' would work. It appears as though they convinced at least some of their colleagues of the worth of such a policy instrument.

Since the adoption of the Directive, the EU has served as a platform for the promotion of such measures in other ways. In September 2008 the European Council adopted the European Pact on Migration and Asylum. This Pact was proposed and drafted by France, which held the presidency of the Union at the time. While it is not legally binding upon the member states, this Pact was signed by the highest political organ in the European Union and therefore carries great political weight. It states that the European Council has agreed 'to regulate family migration more effectively by inviting each Member State (...) to take into consideration (...) families' capacity to integrate, as evaluated by (...) for example, their knowledge of that country's language'(European Council 2008, paragraph I.d). In the Family Reunification Directive, integration measures were still vaguely defined and - most importantly - it was left entirely up to the member states whether they should introduce such measures or not. The Pact goes 
further than that, by explicitly encouraging member states to introduce language requirements for family migrants.

Also, in July 2007, the Council established the European Integration Fund, which is to provide financial support to member states' efforts to improve their migrant integration policies. Among the member states' actions eligible for funding, the Council Decision to establish the Fund lists actions that 'prepare third-country nationals for their integration into host society in a better way by supporting pre-travel measures which enable them to acquire knowledge and skills necessary for their integration' (Council of the European Union 2007, paragraph 4.1.c). Here, member states are encouraged to introduce pre-departure integration measures not just with words, but even with money. According to Groenendijk (2011: 8), 'the Netherlands was instrumental in extending the fund's scope' to these measures.

Thus, the EU has served as a platform for exchange of information about pre-departure integration requirements, as well as for the promotion of such requirements, without however imposing obligations upon member states. In this respect, the proliferation of pre-departure integration requirements is similar to what is usually called 'horizontal Europeanization' in the literature, i.e. 'the diffusion of ideas and discourses about the notion of good policy and best practice' through EU policy and politics, 'where there is no pressure to conform to EU models' (Radaelli 2003: 30, 41). However, the transfer of pre-departure integration contrasts with 'horizontal Europeanisation', in that it was operated exclusively by member states, without support from the Commission and Court. Radaelli (2000: 26) describes the EU as 'a massive transfer platform' where 'the European Commission is a very active policy entrepreneur' as it 'suggests best practices, models and original solutions'. Most accounts of horizontal Europeanisation focus on mechanisms such as the Open Method of Coordination (Trubek et al 2005; Radaelli 2003) in which the Commission plays a crucial initiating, facilitating and coordinating role (Telò 2002; De Ruiter 2010). In the case of the transfer of pre-departure integration measures however, the Commission has not played this enabling role: to the contrary, it has tried to obstruct the transfer.

From the very start of the negotiations on the Family Reunification Directive, it was clear that the Commission's policy perspective on family migration clashed with that of certain member states. The Commission's original legislative proposal started from the notion that 'family reunion helps to create sociocultural stability facilitating the integration of third country nationals' (Preamble 4 of the Family Reunification Directive). Only as a result of active lobbying by Austria, Germany, and the Netherlands was 
the opposite notion introduced in the Directive, namely that integration might be a precondition for family migration rights (Groenendijk 2004). Until today, the Commission actively resists this notion.

In its 2008 report on the implementation of the Family Reunification Directive, the Commission was very critical about integration measures as a condition for family migration, stating that the aim of such measures should be 'to facilitate the integration of family members'. It questioned the admissibility of policies such as those conducted in the Netherlands and Germany, with high exam fees and inaccessible courses, which the Commission thought likely to result in exclusion, rather than in integration (European Commission 2008: 7-8).

The EU Court of Justice has adopted an interpretation of the Directive which is quite similar to the Commission's approach. In 2006, it ruled that the Family Reunification Directive grants a subjective right to family reunion, and that member states' policies should reflect the objective of the Directive, i.e. 'facilitating the integration (...) by making family life possible through reunification' (Case $\mathrm{C}-540 / 03)$. Reflecting this positive attitude to family reunification, the Court declared in its 2010 Chakroun ruling that the Dutch income requirement of $120 \%$ of the minimum wage was too high (Case C-578/o8). The Court has not yet ruled about the admissibility of pre-departure integration requirements. However, based on the EU Court's jurisprudence on the EU-Turkey Association Agreement, national courts in both the Netherlands (LJN BR4959) and Austria (VwGH 2008/22/0180) have ruled that sharpened integration and family migration policies for Turkish citizens are incompatible with this Agreement. Hence, Turkish citizens are exempted from pre-departure integration requirements in the Netherlands and Austria.

In March 2011, the EU Court of Justice was asked to determine whether the Dutch policy of requiring family migrants to pass an integration exam before admission was compatible with the Directive. However, in the course of the proceedings the Dutch government granted a permit to the Afghan woman whose husband had initiated the case, after which the Court deemed a ruling unnecessary. It is perhaps no coincidence that the Dutch government granted this permit - thus avoiding a Court ruling - shortly after the Commission had presented its opinion to the Court. This opinion was unequivocal: the Commission advised the Court to rule that '(...) the directive does not allow for a family member (...) to be denied entry and stay only because this family member has not passed the integration exam abroad (...)' (European Commission 2011). 
This Commission opinion has not escaped the notice of national courts. In 2012, a Dutch court of first instance ruled that pre-departure integration measures were inadmissible under EU Law (Awb 12/9408). In October 2011, the German Federal Administrative Court ruled that the EU Court should be asked to clarify whether pre-departure integration measures are compatible with the Family Reunification Directive (BVerwG 1 C 9.10). Thus far, the German government has been able to prevent the EU Court from ruling on the matter, by granting visas in every case which was (likely to be) referred to the EU Court for a preliminary ruling (Block and Bonjour 2013). However, in March 2013, the question was once again posed to the EU Court by a German court (C-138/13, Dogan) and at the moment of writing this article (January 2014), the Court proceedings had not been interrupted.

In the meantime, the Commission appears determined to use all means at its disposal to combat pre-departure integration requirements for family migrants. In May 2013, the Commission sent a Letter of Formal Notice to the German government about its pre-departure language requirement, thus initiating the first phase of infringement proceedings (European Commission 2013). In response, the German government maintains that its current policies are compatible with the Family Reunification Directive (German Lower House 2013: 16). If Germany persists, the Commission may eventually ask the EU Court to rule directly on the admissibility of pre-departure integration requirements.

Thus, the EU served as a platform for the diffusion and promotion of policy concepts, thereby providing the opportunity for the transfer of pre-departure integration requirements. However, unlike the common representation of horizontal Europeanisation in the literature, this process occurred against the express opposition of the Commission, rather than with its support. Member states have been the only agents of transfer.

\section{Legitimacy in shared practice: references to transfer in political debates}

In sum of the argument in the previous section, the transfer of pre-departure integration requirements among EU member states cannot be explained as the result of supranational coercion or pressure: it was a voluntary process initiated by member states themselves.

In the literature on policy transfer, the dominant assumption is that voluntary transfer is a rational process, in which governments seek information about policy practices elsewhere to identify the most effective solution 
to their policy problem. It is acknowledged that actors' rationality is often 'bounded' but this is described as the result of incomplete information or external pressure (Dolowitz and Marsh 2000; cf. Holzinger and Knill 2005). In contrast, neo-institutional approaches to policy transfer emphasise that transfer is not a rational problem-solving strategy, but 'the expression of a need of legitimation': transfer serves primarily to show that the chosen course of action is a 'entirely appropriate means to achieve a socially valued goal'. Particularly where a policy proposal is (likely to be) controversial, "presenting a measure as a "solution that works" abroad is part of a strategy aimed at naturalising a political choice' (Delpeuch 2008: 10, 14).

As we shall see below, the process of transfer of pre-departure integration requirements confirms the neo-institutionalist view, rather than the rationalist view. If the transfer had been part of a rational problem-solving strategy, then member states would have collected all information available to identify the most effective policy solution. Nothing indicates however that member states were interested in whether pre-departure integration requirements actually worked, that is in their effects. The information collected about other countries' policy practices was very limited, especially with regard to policy effects. For instance, no reference at all is made to policy evaluations - such as the 'Monitor Civic Integration Exam Abroad' which was published by the Dutch government at least once a year since November 2007. One might argue that such 'rational policy-learning' is more likely to occur at the level of civil servants, than at the level of parliamentary debates analysed here. However, if information about the effects of other countries' policy practices which supported the introduction of pre-departure integration requirements had been collected during the administrative preparation of policy proposals, there would be no reason for governments to refrain from sharing this information with Parliament. None of the governments presented such information. In fact, when a UK Liberal Democrat MP requested the Minister to 'ask the Netherlands Government whether they sought advice from independent agencies on the effects of their tests on integration', the government simply failed to respond (UK House of Lords 2010). This suggests that the aim of transfer was not rational problem-solving, but creating legitimacy for pre-departure integration requirements. In the UK as in the other member states, predeparture integration requirements were justified not by showing that similar measures actually worked elsewhere, but only by arguing that they were also implemented elsewhere, as I will illustrate below. In essence, this boils down to the playground argument: 'it's alright, because the others are doing it too'. Politicians sought to build legitimacy for pre-departure 
integration measures not by proving their effectiveness, but by representing them as a shared practice among EU member states.

The Family Reunification Directive was also referred to as a source of legitimacy, but only to a very limited extent. The Dutch, French, and German governments referred to the Directive in the Explanatory Memoranda which accompanied their legislative proposals to introduce predeparture integration requirements. However, the German and almost all the Dutch references were 'weak' legitimacy arguments, limited to stating - truthfully - that EU law allows but does not oblige member states to introduce integration measures for family migrants. The single occasion where the Dutch government presented the EU as a somewhat stronger source of legitimacy was its claim that 'the new integration requirement fits with recent developments in European migration law', such as the Family Reunification Directive (Dutch Lower House 2004a: 16-17). The French government employs a similar formulation, stating that 'these measures are fully in line with the Family Reunification Directive' (French Lower House 2007a). The UK and Austrian governments do no mention the Directive at all, either in policy documents or in parliamentary debates - an omission which is understandable in the British case since the UK is not bound by the Directive, but quite striking in the Austrian case.

The limited reference to the Directive as a source of legitimacy is less surprising when one takes into account that the scope which the Directive allows for integration measures has long been subject to debate among politicians and law scholars (cf. Groenendijk 2011). From the first debates about pre-departure integration measures until today, the German and Dutch left-wing opposition have questioned the government about the compatibility of this measure with article 7.2 of the Directive (Dutch Lower House 2006, 2008a; German Lower House 2007, 2008, 2009a, 2009b, 2010, 2011). The Commission's critical report of 2008 and its unequivocal dismissal of pre-departure integration tests in 2011 as contrary to the Directive have only increased the controversial nature of these measures and thereby increased the need for legitimation, while weakening if not disqualifying the Family Reunification Directive as a source of legitimacy. Politicians therefore looked for legitimation elsewhere, namely in the practices of other member states.

In the course of the Austrian parliamentary debate about pre-departure integration measures, a member of the Christian Democrat coalition party ÖVP remarked: 
This is not a monstrosity or harassment, as it is sometimes presented. In other countries, this is self-evident and in Germany for instance it has been law since 2007 (Austrian Lower House 2011: 115).

The UK government referred to other countries' policies repeatedly when defending its plans to introduce a language requirement for spouses. In 2009 for instance the government stated:

This policy is in line with thinking in other EU states: the Netherlands, Germany and Denmark have all introduced pre-entry language requirements, with France also introducing new exams on French language and culture pre-entry for family reunification applications in the near future (UK Border Agency 2009: 23).

Thus, other countries sharing the same policy practice represent a source of legitimacy. This is confirmed by the German far-Left opposition attacking government policy precisely for not following the majority of other European countries. Die Linke and the Greens referred to the government's plan to introduce pre-departure integration measures as a 'restrictive Sonderweg', which a member of the Christian Democrat coalition party countered by stating that 'This is not true. (...) The Netherlands! France! More and more countries are opting for this instrument!' (German Lower House 2009b: 2, 2009c: 22640)

France finally is the country where the reference to other countries was most explicitly and elaborately put forward in defence of the government proposal to introduce pre-departure integration measures for family migrants. This policy proposal was first launched by parliamentarian Thierry Mariani, member of the right-wing coalition party UMP, in an information report about Migrant integration policies in the European Union which he presented to Parliament in December 2006 (French Lower House 2006). The purpose of the report was to identify good practices in other countries which might help improve French integration policies:

All immigration countries are confronted, to a different degree, to similar difficulties. Why not be inspired by the good ideas, the good practices of our neighbours - they often have good ideas - and by what works for them?

In this report, Mariani examined the migrant integration policies of the US and Canada, i.e. two 'old immigration countries', as well as of Denmark, Germany, the Netherlands, Sweden, and the United Kingdom, selected 
'because the integration policies they conduct are particularly interesting'. According to Mariani, his analysis showed that 'more and more countries tend to turn integration into a condition for admission, so as to start the integration effort as early as possible'. Mariani discussed Dutch pre-departure integration measures and German and Danish plans to introduce similar policies, and concluded that this 'testifies to a real European convergence on this point'. The first among the recommendations with which Mariani concludes his report is for France to 'implement an integration test abroad for family migrants', following the Dutch, German and Danish example. This example confirms that policy makers involved in policy transfer are not rational learners who collect as much information as possible to choose the best policy option (Holzinger and Knill 2005: 783). Rather, policy makers consider only a limited number of policy options implemented in other countries, selected according to a political rather than a scientific logic (Delpeuch 2008: 50). The five EU member states which Mariani selected are those with the most elaborate language and civic integration programs or requirements for migrants. Only on the basis of such a selective comparison could he have come to the conclusion that there is a 'real European convergence' around pre-departure integration measures, which after all had been adopted by no more than three out of 27 member states at the time. The selection of information collected for this report then was clearly based on political motives, i.e. on the wish to legitimate the proposal to introduce pre-departure integration measures.

Mariani's recommendation was taken over by Nicolas Sarkozy, then Minister of the Interior and candidate in the presidential elections. In a speech he made in March 2007, Sarkozy copied Mariani's argument about 'European convergence' literally:

I want us to follow the example of the Netherlands, which has put in place an integration test for family migrants to take in their country of origin. Germany and Denmark plan to adopt a similar test, which marks a real European convergence' (Sarkozy 2007).

In the parliamentary debates about pre-departure integration measures, the government and the majority MPs referred to the fact that similar measures were implemented in other European countries as proof of their legitimacy. Thus minister Hortefeux declared that by creating this test and this course, France joins the ranks of several large European countries'such as the Netherlands and Germany (French Upper House 2007). His referral to the Netherlands as a 'large' European country reveals Hortefeux' wish 
to present the Netherlands as an appropriate model to follow. Similarly, a UMP member of parliament stated:

This is not a leap into the unknown but an adaptation to the European norm: the Netherlands have put in place a pre-departure integration test for family reunification in March 2006, and Germany and Denmark plan to implement it (French Lower House 2007b).

This quote illustrates clearly that what is perceived among politicians as 'the European norm' consists not only of formal EU law, but also and even primarily of what is presented as common practice among EU member states.

That politicians find legitimacy in shared policy practice is evident not only in the references by policy-makers who imported pre-departure integration models, but also in debates among politicians of the main exporter: the Netherlands. Thus the Greens, in an early stage of debates about the integration abroad requirement, pointed out that if the Netherlands went through with this reform, it would be 'the only country in the whole world to require language skills as a condition for the admission of family migrants' (Dutch Lower House 2004b: 12). The argument the Greens were trying to make here was that this was an all too extreme measure which the Netherlands should refrain from implementing. Minister Verdonk, a Conservative Liberal, confirmed that the Netherlands would be the only country in the European Union to impose such a condition, but added that 'I can assure you that my colleague ministers are observing this with great interest' (Dutch Lower House 2004b: 42). Thus the government turned the argument around, presenting the Netherlands as 'acting as a pioneer for other countries to follow' (Dutch Lower House 2008b:4). A couple of months after the Law on Civic Integration Abroad was adopted, the government added:

The Netherlands are taking the lead in Europe when it comes to civic integration abroad. Many member states are following these developments with great interest. (...) I expect that other member states will follow our example after we have gained some experience with it and that our system of civic integration abroad will serve as an example for other member states (Dutch Lower House 2005: 15).

The Netherlands was the very first country in the Union to introduce integration requirements as a general condition for the admission of family 
migrants and it did not feel comfortable in this outlier position. Dutch politicians therefore actively engaged in turning integration abroad into a common practice among member states. Having other member states follow its lead gave Dutch civic integration policy the legitimacy of serving as a role model, rather than remaining an extreme and exceptional case. This is why the Dutch pushed for the inclusion of pre-departure integration measures among the actions eligible for financial support from the European Integration Fund. It is also why the French tried to encourage other member states to introduce language requirements for family migrants by including this policy measure in the European Pact on Migration and Asylum. To make sure that their policies fitted comfortably within the European norm - in the sense of common, accepted practice among member states - Dutch and French politicians endeavoured to modify this norm.

\section{Conclusion}

Over the last decade, six EU member states have introduced pre-departure integration requirements for family migrants. This policy instrument has proliferated through a voluntary mechanism of transfer with the European Union serving as a platform for the exchange of information and ideas among national policy-makers. Because of its voluntary nature, this transfer is similar to 'horizontal Europeanisation' but it differs from mechanisms such as the Open Method of Coordination in that the European Commission opposed rather than supported it. Member states were the only agents of transfer.

An analysis of political debates in five out of the six countries which introduced pre-departure integration measures has shown that transfer is a process aimed not a rational problem-solving, that is at identifying the policy solution that works best, but at creating legitimacy. Politicians seek to justify pre-departure integration measures not by showing that pre-departure measures have proven effective elsewhere, but merely by presenting such measures as a policy practice shared with other member states. Politicians in both the exporting and the importing countries refer to other countries conducting similar policies to legitimise pre-departure integration measures. The 'vertical' legitimacy of pre-departure integration measures, derived 'top-down' from formal EU legislation, appears problematic, as the compatibility of pre-departure integration measures with EU law is subject to increasing debate, with the Commission in particular adopting a critical stance. This is why member states adopt 'horizontal' 
legitimacy seeking strategies, where policy legitimacy is derived not from formal legal norms, but from policy practices shared with other countries.

The on-going process of Europeanisation of migrant integration policies is a multifaceted process, a 'struggle' as Carrera (2006:13) puts it both about the approach to be adopted and about the repartition of competences. This analysis of the transfer of pre-departure integration measures among EU member states draws attention to one of the dynamics - and perhaps the main dynamic - through which this Europeanisation is evolving. What we have observed here is a process of policy transfer driven by (a select group of) member states against the express opposition of the Commission, where policy-making derives legitimacy not from formal European norms, but from shared policy practice.

\section{Notes}

1. As we shall see later, Denmark is something of an exception, since family migrants are allowed to enter Denmark for 3 months to take the test, rather than taking the test abroad as the other five countries require.

2. Research Project on Promoting Sustainable Policies for Integration (PROSINT): http:// research.icmpd.org/1428.html. Research program on Integration and Naturalisation Tests (INTEC): http://www.ru.nl/law/cmr/projects/overview/intec/.

3. However, the secondary literature suggests that the process of transfer in Denmark showed strong similarities to my findings in the other five countries. Pre-departure integration tests were explicitly presented by the Danish government as 'following the Dutch example', but requests from the opposition for information about the effects of these Dutch policies were not followed up by the government (Ersbøll 2010: 128-132; Ersbøll \& Gravesen 2010: 22-23).

4. This overview is based on the comparative analysis of pre-departure integration measures in Germany, the Netherlands, and the UK presented in Scholten et al (2012), complemented with data on the French case presented in Pascouau (2010) and on the Danish case presented in Ersbøll \& Gravesen (2010), as well as with data on the Austrian case provided by the Austrian Ministry of the Interior (2012).

5. Persons who are not citizens of the EU, Norway, Iceland, Liechtenstein, or Switzerland.

\section{References}

Austrian Lower House (2011). Protokoll 103. Sitzung des Nationalrates, 29 April 2011 (http://www. parlament.gv.at/PAKT/VHG/XXIV/NRSITZ/NRSITZ_o0103/).

Austrian Ministry of the Interior (2012). Family reunification. (http://www.bmi.gv.at/cms/ BMI_Niederlassung/english/files/Family_Reunification_2012_02_07.pdf).

Böcker, A. \& Strik, T. (2011). Language and Knowledge Tests for Permanent Residence Rights: Help or Hindrance for Integration? European Journal of Migration and Law 13(2): 157-184.

Block, L. (2012). Regulating Social Membership and Family Ties. Policy Frames on Spousal Migration in Germany. PhD Thesis. Florence, European University Institute. 
Block, L. \& Bonjour, S. (2013). Fortress Europe or Europe of Rights? The Europeanisation of family migration policies in France, Germany and the Netherlands. European Journal of Migration and Law 15(2): 203-224.

Bonjour, S. (2010). Between Integration Provision and Selection Mechanism. Party Politics, Judicial Constraints, and the Making of French and Dutch Policies of Civic Integration Abroad. European Journal of Migration and Law, 12(3): 299-318.

Bonjour, S. \& Vink, M. (2013). When Europeanization backfires. The normalization of European migration politics. Acta Politica 48(4):389-407.

Bonjour, S. \& Kraler, A. (forthcoming). Introduction: Family migration as an integration issue? Policy perspectives and academic insights. Journal of Family Issues.

Borevi, K. (forthcoming). Family Migration Policies and Politics: Understanding the Swedish Exception. Journal of Family Issues.

Carrera, S. (2006). A Comparison of Integration Programmes in the EU. Trends and Weaknesses. Challenge Papers. Brussels: CEPS (http://www.ceps.eu/book/comparison-integrationprogrammes-eu-trends-and-weaknesses).

Carrera, S. \& Wiesbrock, A. (2009). Civic Integration of Third-Country Nationals. Nationalism versus Europeanisation in the Common EU Immigration Policy. Brussels: CEPS (http:// www.ceps.be/book/civic-integration-third-country-nationals-nationalism-versuseuropeanisation-common-eu-immigrat).

Council of the European Union (2007). Council Decision of 25 June 2007 establishing the European Fund for the Integration of third-country nationals. Council Decision 2007/435/EC (http://eur-lex.europa.eu/LexUriServ/LexUriServ.do?uri=OJ:L:2007:168:0018:0036:EN:PDF).

Delpeuch, T. (2008). L'analyse des transferts internationaux de politiques publiques: un état de l'art. Questions de Recherche No 27. Paris : Centre d'études et de recherches internationales, Sciences Po. (http://www.sciencespo.fr/ceri/sites/sciencespo.fr.ceri/files/qdr27.pdf)

Dolowitz, D. P. \& Marsh, D. (200o). Learning from Abroad: The Role of Policy Transfer in Contemporary Policy-Making. Governance $13(1): 5$-24.

De Ruiter, R. (2010). Variations on a Theme. Governing the Knowledge-Based Society in the EU through Methods of Open Coordination in Education and R\&D. Journal of European Integration 32(2): 157-173.

Dutch Lower House (2000). TK 1999-200o Plenary 18 and 20 April 200o, pp. 4713-4714, 4748. (https://zoek.officielebekendmakingen.nl/zoeken/parlementaire_documenten)

Dutch Lower House (2004a). TK 2003-2004 29700 Nr. 3 (https://zoek.officielebekendmakingen. $\mathrm{nl} /$ zoeken/parlementaire_documenten).

Dutch Lower House (2004b). TK 2003-2004 27083 Nr. 44 (https://zoek.officielebekendmakingen. $\mathrm{nl} /$ zoeken/parlementaire_documenten).

Dutch Lower House (2005). TK 2005-2006 30308 Nr. 7 (https://zoek.officielebekendmakingen. $\mathrm{nl} /$ zoeken/parlementaire_documenten).

Dutch Lower House (2006). TK 2005-2006 2970o Plenary p. 6o-3897, 16 March 2006 (https://zoek. officielebekendmakingen.nl/zoeken/parlementaire_documenten).

Dutch Lower House (2008a). TK 2008-2009 Appendix to Proceedings Nr 845 (https://zoek. officielebekendmakingen.nl/zoeken/parlementaire_documenten).

Dutch Lower House (2008b). TK 2007-2008 29700 Nr. 54 (https://zoek.officielebekendmakingen. nl/zoeken/parlementaire_documenten).

Ersbøll, E. (2010). On Trial in Denmark. In: R. van Oers, E. Ersbøll \& T. Kostakopoulou (eds.), A Re-Definition of Belonging? Language and Integration Tests in Europe. Leiden: Brill, $p p$. $107-152$.

Ersbøll, E. \& Gravesen, L.K. (2010). Country Report Denmark. INTEC Report. Nijmegen: Centre for Migration Law (http://www.ru.nl/law/cmr/projects/intec/). 
European Commission (2008). Report from the Commission to the European Parliament and the Council on the application of directive $2003 / 86 /$ ec on the right to family reunification. $\operatorname{COM}(2008) 610$ final (http://eur-lex.europa.eu/LexUriServ/LexUriServ.do?uri=COM:2008: o610:FIN:EN:PDF).

European Commission (2011). Written Declaration submitted on 4 May 2011 to the EU Court of Justice in the case C-155/11. Document nr. Sj.g.(2011)540657.

European Commission (2013). DG Home Affairs, Immigration and Integration Infringements (http://ec.europa.eu/dgs/home-affairs/what-is-new/eu-law-and-monitoring/infringements_by_policy_immigration_and_integration_en.htm).

European Council (2008). European Pact on Immigration and Asylum. Council document 13440/o8 (http://register.consilium.europa.eu/pdf/en/o8/st13/st13440.eno8.pdf).

Eurostat (2011a). $6.5 \%$ of the EU population are foreigners and $9.4 \%$ are born abroad. Statistics in focus 34 (http://epp.eurostat.ec.europa.eu/portal/page/portal/product_details/ publication?p_product_code=KS-SF-11-034).

Eurostat (2011b). Indicators of Immigrant Integration. A Pilot Study. Eurostat Methodologies and Working Papers (http://epp.eurostat.ec.europa.eu/cache/ITY_OFFPUB/KS-RA-11-0og/ EN/KS-RA-11-oog-EN.PDF).

French Lower House (2006). Rapport d'information $\mathrm{N}^{\circ} 35^{\circ} 2$ sur les politiques d'intégration des migrants dans l'Union européenne, 6 December 2006 (http://www.assemblee-nationale. fr/12/europe/rap-info/i3502.asp).

French Lower House (2007a). Projet de Loi No 57 relatif à la maitrise de l'immigration, à l'intégration et à l'asile, 4 July 2007 (http://www.assemblee-nationale.fr/13/projets/ploo57. asp).

French Lower House (2007b). Plenary 18 September 2007 (http://www.assemblee-nationale. $\mathrm{fr} / 13 /$ dossiers/immigration_integration_asile.asp).

French Upper House (2007). Plenary 2 October 2007 (http://www.assemblee-nationale.fr/13/ dossiers/immigration_integration_asile.asp).

German Lower House (2007). 40. Sitzung Innenausschuss $N^{\circ}$ 16/40, 21 May 2007 (http://dipbt. bundestag.de/dip21.web/bt)

German Lower House (2008). Druksache16/10732, 29 October 2008 (http://dipbt.bundestag. de/dip21.web/bt).

German Lower House (2009a). Drucksache 16/12979, 8 May 2009 (http://dipbt.bundestag.de/ dip21.web/bt).

German Lower House (2009b). Drucksache 11/11997, 16 February 2009 (http://dipbt.bundestag. de/dip21.web/bt).

German Lower House (2009c). Plenarprotokoll 16/209, 6 March 2009 (http://dipbt.bundestag. de/dip21.web/bt).

German Lower House (2010). Drucksache 17/1572, 4 May 2010 (http://dipbt.bundestag.de/dip21. web/bt).

German Lower House (2011). Drucksache 17/5732, 5 May 2011 (http://dipbt.bundestag.de/dip21. web/bt).

German Lower House (2013). Drucksache 17/14337, 5July 2013 (http://dipbt.bundestag.de/dip21. web/bt).

Goodman, S.W. (2010). Integration Requirements for Integration's Sake? Identifying, Categorising and Comparing Civic Integration Policies. Journal of ethnic and migration studies $36(5)$ : 753-772.

Goodman, S.W. (2011). Controlling Immigration through Language and Country Knowledge Requirements. West European Politics 34(2): 235-255. 
Groenendijk, K. (2004). Legal Concepts of Integration in EU Migration Law. European Journal of Migration and Law 6(2): 111-126.

Groenendijk, K. (2011). Pre-departure Integration Strategies in the European Union: Integration or Immigration Policy? European Journal of Migration and Law 13(1): 1-30.

Guild, E., Groenendijk, K. \& Carrera, S. (2009). Understanding the Contest of Community : Illiberal Practices in the EU? In: E. Guild, K. Groenendijk, S. Carrera (eds.), Illiberal Liberal States. Immigration, Citizenship and Integration in the EU. London: Ashgate, pp. 1-25.

Holzinger, K. \& Knill, C. (2005). Causes and conditions of cross-national policy convergence. Journal of European Public Policy 12(5): 775-796.

Jacobs, D. (2011). The impact of substate nationalism and 'horizontal' Europeanization on migration policy: the case of family reunification in Belgium. Paper presented at the Council for European Studies Conference, Barcelona, 21 June 2011.

Jacobs, D. \& Rea, A. (2007). The End of National Models? Integration Courses and Citizenship Trajectories in Europe. International Journal on Multicultural Societies 9(2): 264-283.

Joppke, C. (2007). Beyond National Models: Civic Integration Policies for Immigrants in Western Europe. West European politics 3o(1): 1-22.

Pascouau, Y. (2010). Country Report France. INTEC Report. Nijmegen: Centre for Migration Law (http://www.ru.nl/law/cmr/projects/intec/).

Radaelli, C. M. (200o). Policy Transfer in the European Union: Institutional Isomorphism as a Source of Legitimacy. Governance 13(1): 25-43.

Radaelli, C. M. (2003). The Europeanization of Public Policy. In: K. Featherstone, C. Radaelli, M. (eds.), The Politics of Europeanization. Oxford: Oxford University Press, pp. 27-56.

Sarkozy, N. (2007). Déclaration sur le bilan de la politique de l'immigration et de l'aide au développement, Marseille, 5 March 2007 (http://discours.vie-publique.fr/notices/073000867.html)

Scholten, P.W.A., Entzinger, H., Kofman, E., Hollomey, D. \& Lechner, C. (2012). Integration from abroad? Perception and impacts of pre-entry tests for third-country nationals. PROSINT Comparative Reports WP4 (http://research.icmpd.org/fileadmin/Research-Website/ Project_material/PROSINT/Reports/WP4_CompRep_Final_submitted.pdf).

Seveker, M. \& Walter, A. (2010). Country Report Germany. INTEC Report. Nijmegen: Centre for Migration Law (http://www.ru.nl/law/cmr/projects/intec/).

Strik, T. (2011). Besluitvorming over asiel- en migratierichtlijnen. De wisselwerking tussen nationaal en Europees niveau. Den Haag: Boom Uitgevers.

Telò, M. (2002). Governance and Government in the European Union: the Open Method of Coordination. In: M. J. Rodriguez (ed.), The New Knowledge Economy in Europe. Cheltenham: Edward Elgar, pp. 242-27ı.

Trubek, D. M., Cottrel, P. \& Nance, M. (2005). “Soft Law”, "Hard Law”, and European Integration: Toward a Theory of Hybridity. Paper published online at http://law.wisc.edu/facstaff/trubek/ hybriditypaperapril2005.pdf.

UK Border Agency (2009). Earning the Right to Stay: A New Points Test for Citizenship. London: UKBA (http://webarchive.nationalarchives.gov.uk/20090713010115/http://www.ukba. homeoffice.gov.uk/sitecontent/documents/aboutus/consultations/221878/earning-theright-to-stay/earning-the-right-to-stay/earned-citizenship-consultation?view=Binary).

UK House of Lords (2010). Lords Hansard 25 October 2010, Column 1095 (http://www.parliament. uk/business/publications/hansard/lords/).

Van Oers, R., Ersbøll, E. \& Kostakopoulou, T. (eds.) (2010). A Re-definition of Belonging? Language and Integration Tests in Europe. Leiden: Brill. 


\section{About the author}

Saskia Bonjour is a research fellow at the Leiden University Institute for History. Contact information and publications: http://www.hum.leiden.edu/history/staff/ bonjoursa.html.

Email: s.a.bonjour@hum.leidenuniv.nl.

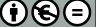

This is an Open Access article distributed under the terms of the Creative Commons Attribution License (http://creativecommons.org/licenses/by/2.0), which permits unrestricted use, distribution, and reproduction in any medium, provided the original work is properly cited. 